\title{
The Manitoba Community Intravenous Therapy Program: Then and now
}

Shurjeel H Choudhri MD FRCPC

\section{BACKGROUND}

The Manitoba Community Intravenous Therapy Program (MCITP) arose out of a study conducted between 1976 and 1977 by Stiver et al (1) that demonstrated the feasibility, safety, efficacy and cost effectiveness of providing home intravenous (IV) therapy. Study patients also gained significant psychological benefits from home treatment (2). In 1978, these findings were used to develop a proposal for a provincially funded community intravenous therapy program (3).

The initial proposal for provincial funding was unsuccessful. Between 1977 and 1981, an nonfunded service was provided on an ad hoc basis through the cooperation of the Departments of Pharmacy and Infectious Diseases at the St Boniface General Hospital (SBGH) and the Victorian Order of Nurses. The lack of funding resulted in numerous service interruptions due to staffing and financial difficulties. In 1978, the Department of Continuing Care agreed to provide funds for the IV supplies, but not the drugs required for home therapy. It was not until 1981 that the Manitoba Health Services Commission (MHSC) agreed to provide continuing funding for the Home IV Program.

Dr Stiver left Manitoba in 1980 and the program leadership was assumed by the SBGH Director of Pharmacy, with some support from the Section of Infectious Diseases. The program operated until February 1996 when MHSC (Manitoba Health) agreed to fund a major expansion of the program. The number of daily treatment slots available was expanded from 13 to 30 , and the program was opened to patients who were unable to self-administer their IV medications. Infectious diseases support was also formalized, with the addition of an infectious diseases consultant to the MCITP team.

\section{THE WAY WE WERE}

From its inception, the MCITP used a multidisciplinary team approach. The initial program team consisted of an in-

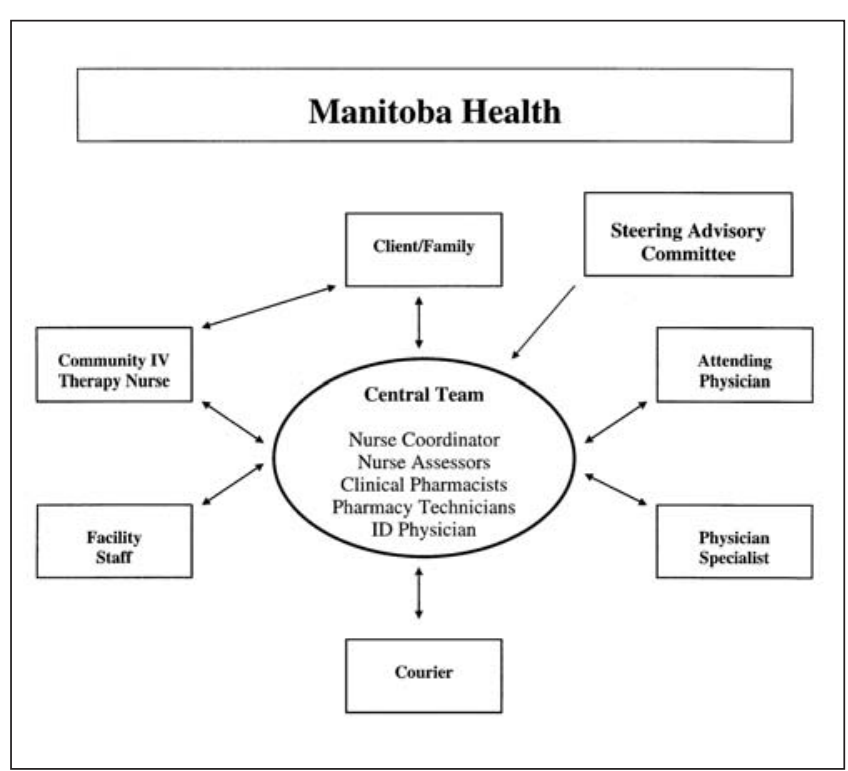

Figure 1) The Manitoba Community Intravenous Therapy Program

fectious diseases physician, a pharmacist, a pharmacy technician and a nurse coordinator (although the infectious diseases participation became somewhat sporadic after the departure of Dr Stiver). Criteria for admission to the program was simple because only self care patients were eligible (Table 1). Patients requiring less than five days of IV therapy were not eligible for the program because of the time required to achieve self-care status. Extensive computerization allowed the program to operate efficiently with a minimal staff component. In its first 12 years, the program treated 748 patients for 15,366 patient days at an average annual cost of $\$ 130,000$ (\$102.00/patient/day) (3). Table 2 lists the most common infections treated by the program in its first 12 years.

Departments of Medicine and Medical Microbiology, University of Manitoba, Winnipeg, Manitoba

Correspondence: Dr Shurjeel H Choudhri, Departments of Medicine and Medical Microbiology, University of Manitoba,

C5124 - 409 Tache Avenue, Winnipeg, Manitoba R2H 2A6. Telephone 204-812-2186, fax 204-812-2186, e-mail schoudri@snet.net 
TABLE 1

Criteria for patient admission into the Manitoba Community Intravenous Program (MCIP)

\begin{tabular}{|c|c|}
\hline \multicolumn{2}{|c|}{ Eligibility criteria } \\
\hline 1978 & 1998 \\
\hline $\begin{array}{l}\text { 1. All signs and symptoms of } \\
\text { infection are being controlled } \\
\text { by treatment. }\end{array}$ & $\begin{array}{l}\text { 1. The client must be a resident of } \\
\text { Manitoba and be registered } \\
\text { with the Manitoba Health } \\
\text { Services Commission. }\end{array}$ \\
\hline $\begin{array}{l}\text { 2. Patient and family understand } \\
\text { the need for continued } \\
\text { intravenous therapy and agree } \\
\text { with the treatment plan. }\end{array}$ & $\begin{array}{l}\text { 2. The client must be referred by } \\
\text { the attending physician. }\end{array}$ \\
\hline $\begin{array}{l}\text { 3. Patient understands and can } \\
\text { perform the necessary } \\
\text { techniques with the intravenous } \\
\text { system to the satisfaction of the } \\
\text { nurse coordinator. }\end{array}$ & $\begin{array}{l}\text { 3. The client/family/support must } \\
\text { understand the need for } \\
\text { intravenous therapy and the } \\
\text { guidelines prescribed. }\end{array}$ \\
\hline $\begin{array}{l}\text { 4. Patient's veins can withstand } \\
\text { repeated cannulation. }\end{array}$ & $\begin{array}{l}\text { 4. The client must have an } \\
\text { infection or condition that } \\
\text { requires intravenous therapy. }\end{array}$ \\
\hline $\begin{array}{l}\text { 5. If patient is from a rural area, } \\
\text { appropriate medical supervision } \\
\text { and follow-up can be arranged. }\end{array}$ & $\begin{array}{l}\text { 5. The client or guardian must sign } \\
\text { the client teaching checklist. }\end{array}$ \\
\hline \multirow[t]{6}{*}{$\begin{array}{l}\text { 6. Patient has access to a freezer } \\
\text { and telephone at home. }\end{array}$} & $\begin{array}{l}\text { 6. Venous access must be } \\
\text { maintained in the community. }\end{array}$ \\
\hline & $\begin{array}{l}\text { 7. The client must have access to } \\
\text { adequate medical and nursing } \\
\text { support. }\end{array}$ \\
\hline & $\begin{array}{l}\text { 8. The client must have reliable } \\
\text { access to a delivery service and } \\
\text { be available to accept delivery } \\
\text { of supplies during designated } \\
\text { hours. }\end{array}$ \\
\hline & $\begin{array}{l}\text { 9. The client must have access to } \\
\text { a telephone, a refrigerator and } \\
\text { a freezer. }\end{array}$ \\
\hline & $\begin{array}{l}\text { 10. The drugs prescribed must be } \\
\text { on the drug formulary for the } \\
\text { program. }\end{array}$ \\
\hline & $\begin{array}{l}\text { 11. Self-care clients and/or } \\
\text { designate must be willing and } \\
\text { able to learn and to } \\
\text { demonstrate the skills } \\
\text { necessary for intravenous drug } \\
\text { administration in the } \\
\text { community. } \\
\text { 12. Nonself-care clients must } \\
\text { agree to be available at a } \\
\text { predetermined agreed upon } \\
\text { time and location for } \\
\text { intravenous therapy. }\end{array}$ \\
\hline
\end{tabular}

\section{THE WAY WE ARE}

The MCITP continues to use a multidisciplinary team (Figure 1). The central team consists of a nurse coordinator, nurse assessors, clinical pharmacists, pharmacy technicians and an infectious diseases physician. The program now functions seven days a week, $24 \mathrm{~h}$ a day and can enroll both self-care and nonself-care patients. The program also provides IV therapy services to two personal care homes on a test basis. Patients requiring intravenous therapy for less than five days are now eligi-
TABLE 2

Types of infection treated by the program

\begin{tabular}{lclc}
\hline \multicolumn{2}{c}{$\mathbf{1 9 7 8}$ to $\mathbf{1 9 8 9}$} & \multicolumn{2}{c}{$\mathbf{1 9 9 6}$ to $\mathbf{1 9 9 8}$} \\
Infection & Patients & \multicolumn{1}{c}{ Infection } & Patients \\
\hline Bone/joint & 333 & Skin/soft tissue & 617 \\
Cystic fibrosis & 124 & Bone/joint & 214 \\
Miscellaneous & 94 & Respiratory tract & 49 \\
Endocarditis & 53 & Miscellaneous & 47 \\
Abscess & 50 & Urinary tract & 38 \\
Cellulitis & 44 & Bacteremia/sepsis & 36 \\
Bacteremia & 28 & Endocarditis & 33 \\
Mycotic & 22 & Cytomegalovirus & 22 \\
& & prophylaxis & \\
& & Central nervous sys- & 17 \\
& & tem & 10 \\
& & Cytomegalovirus & \\
& & retinitis & Post-transplant \\
Total & & Intra-abdominal/ & 5 \\
\hline
\end{tabular}

ble for the program. Understandably, the eligibility criteria have become more complex, although the basic criteria remain the same (Table 1). The patient case mix has also changed dramatically due to the expanded eligibility criteria (Table 2).

Most patients requiring long term therapy have a peripherally inserted central catheter or a central line inserted to minimize problems with venous access. Extensive use of infusion pumps allows patients to continue their normal activities even if they are on an antibiotic requiring frequent daily dosing. The program continues to make extensive use of computers to maximize efficiency and minimize costs.

Since it expanded in 1996, the program has already treated more patients (1095 patients for 19,345 patient days) than during its first 12 years of operation. Remarkably, despite inclusion of nonself-care patients, the treatment cost at $\$ 92 /$ patient/day is less than what it was 10 years ago. Last year, the program produced an operating surplus of $\$ 16,955$.

\section{THE FUTURE}

A planned phase II expansion would have expanded the program to rural test sites and additional personal care homes. The eventual goal was to create a uniform, province wide program. This is no longer a possibility because Manitoba Health has opted to decentralize its services by creating regional health authorities. The role of the MCITP is now to provide support to regional health authorities who wish to develop home IV therapy programs. There will be a provision for mandatory reporting of statistics to the central program.

\section{REFERENCES}

1. Stiver HG, Telford GO, Mossey JM, et al. Intravenous antibiotic therapy at home. Ann Intern Med 1978;89:690-3.

2. Stiver HG, Trosky SK, Cote DD, Oruck JL. Self-administration of intravenous antibiotics: an efficient, cost-effective home care program. CMAJ 1982;127:207-11.

3. Cote D, Oruck J, Thickson N. A review of the Manitoba home i.v. antibiotic program. Can J Hosp Pharm 1989;42:137-141. 


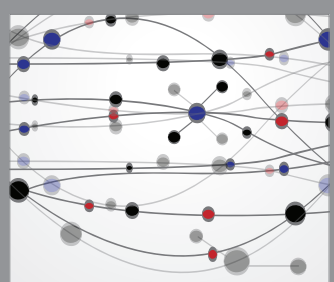

The Scientific World Journal
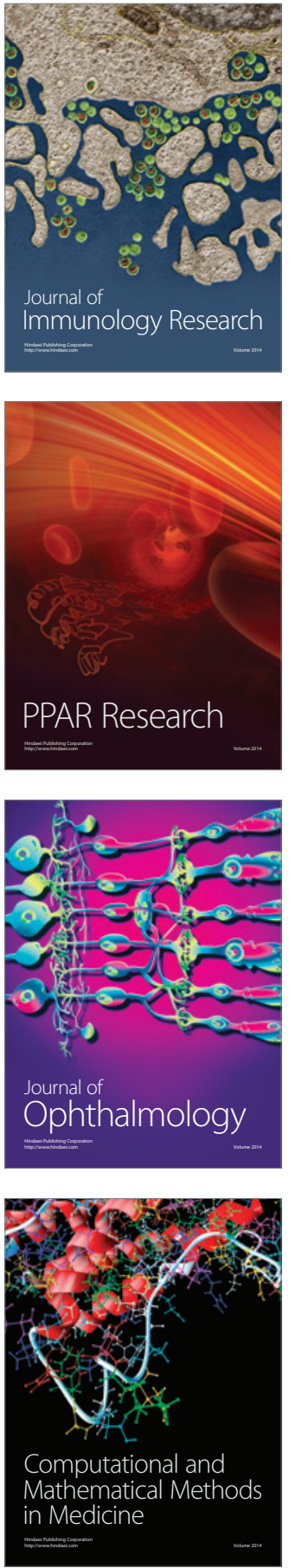

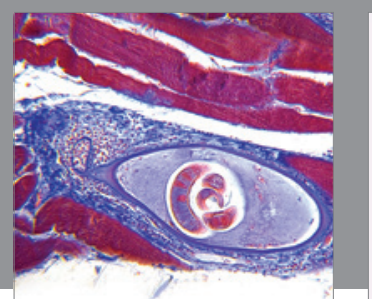

Gastroenterology Research and Practice

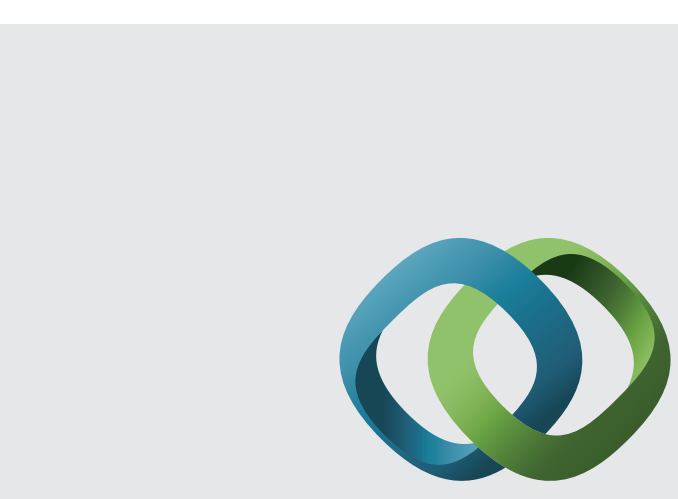

\section{Hindawi}

Submit your manuscripts at

http://www.hindawi.com
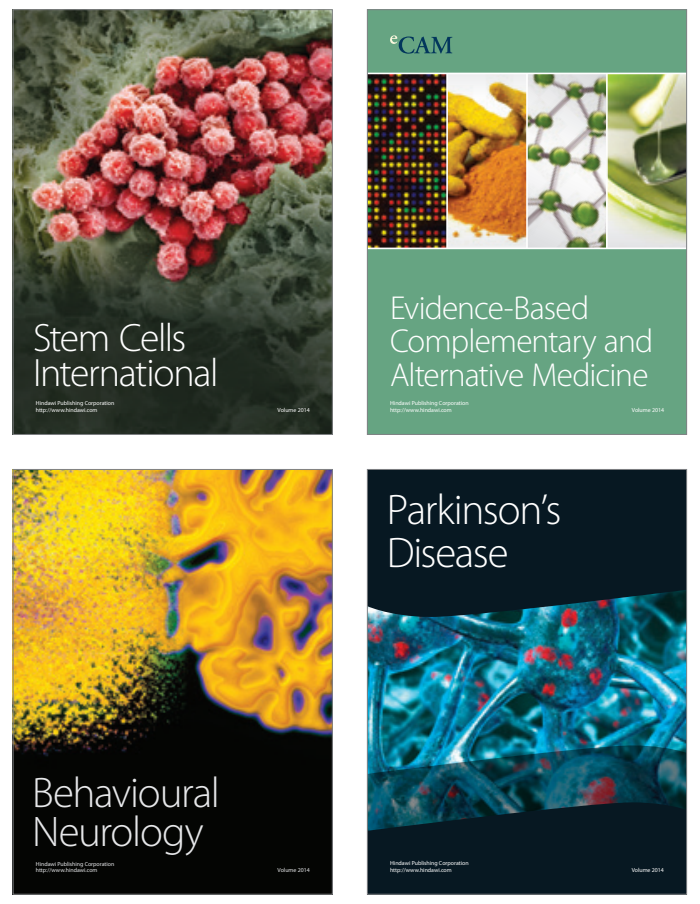
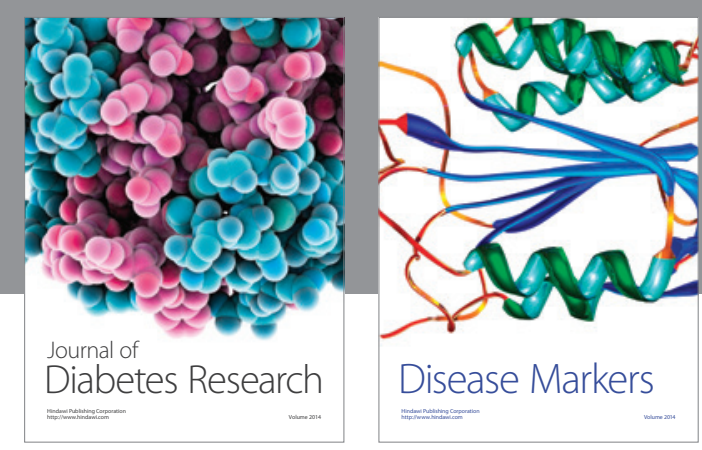

Disease Markers
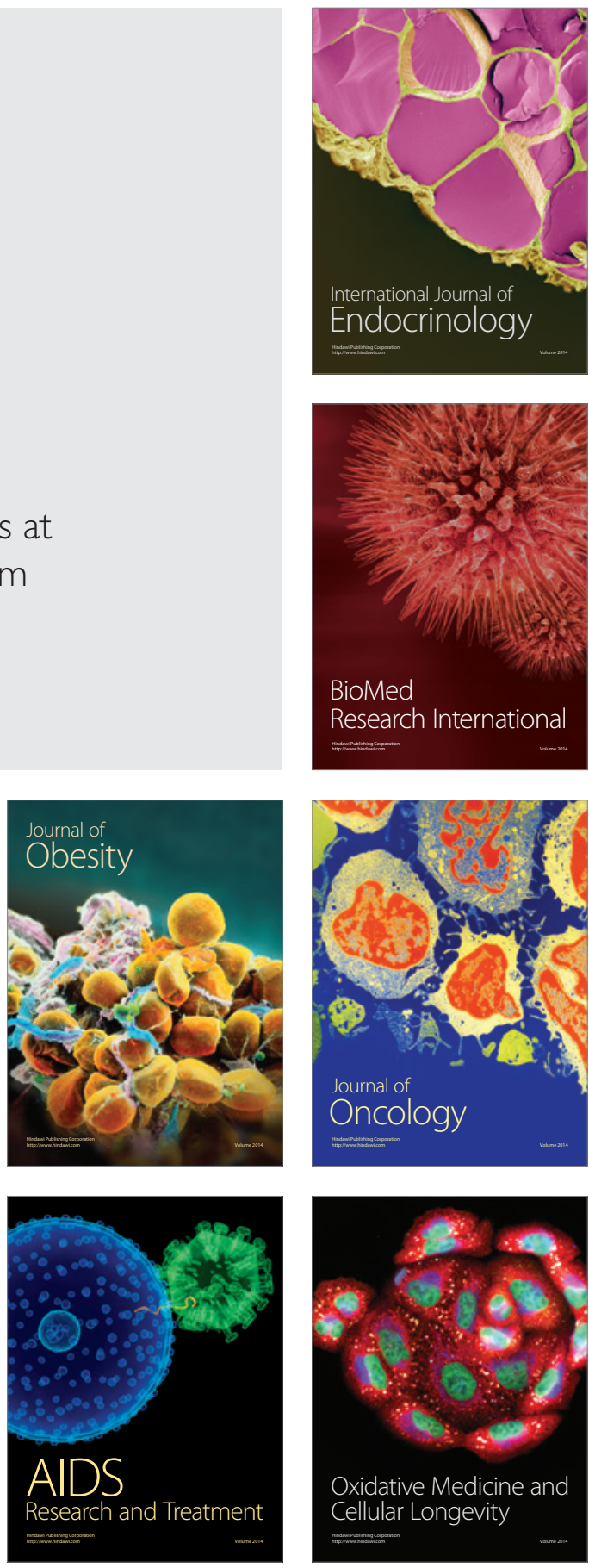